\title{
Lakes as Natural Tourism Object in North Sulawesi
}

\author{
Henny Johanna Kambey ${ }^{1}$, M. Sasmito Djati ${ }^{2 *}$ \\ ${ }^{1}$ Agricultural and Animal Husbandry Office of North Sulawesi, Manado, Indonesia \\ ${ }^{2}$ Department of Biology, Faculty of Mathematics and Natural Sciences, University of Brawijaya, Malang, Indonesia
}

\begin{abstract}
Lake is one of the important natural resources in north Sulawesi and many lakes ecosystem in this province has been used and involved in tourism industry. The aims of the research is to describes the recent status of lakes in North Sulawesi and describes its opportunities for tourism development. The analysis was based on the secondary data and direct field observation. Four lakes, namely Tondano, Pangolombian, Linow and Tampusu have been used as tourism attraction in various degreed. The most intensive used was Lake Tondano, while Lake Linow recently grows as one of the favorites object. Lake Pangolombian and Tampusu receive few tourist visitations. The development of four lakes as tourism object will increase the attractiveness of North Sulawesi as ecotourism development. In such a case, the conservation of lakes becomes crucial.
\end{abstract}

Keywords: economy development, Lake tourism, North Sulawesi.

\section{INTRODUCTION}

Lakes are one of the important ecosystems to support human lives in the earth. Lake resulted from natural geological process which is important in many natural ecological process and maintenance. Lakes has been used for numerous purposes in human being, from socio-cultural and ecological uses. Many communities in the globe depend on lake as crucial resources. Many lakes related to the traditional community live and these relationships between lake and community construct the special iconic of place. Today, lakes is an important resources for modern people, and many of lake become integral part of modern city architecture to create comfort live on crowded area [1].

In human history, lake has provided numerous important contributions to human life. In much traditional community, lake is media for human movement from one place to other place. Lake is source of water for agricultural industry. Lake is reservoir of water and very important resources to continuously provide water for agriculture and industry. Lakes also important attraction for leisure and visiting lakes in recreation programs recently grows significantly [2]. Scholar point out that lake has been visited by thousand of visitor and the contribution to generate local economic was considered important.

\footnotetext{
* Correspondence address:

Henny Johanna Kambey

Address : Jl. Raya Manado Tanawangko, Komplek Pertanian, Kalasey 95041, Manado.
}

Lake, however, facing serious problems related to the future existence. Scholars resume that sedimentation, pollution, overexploitation and invasion of exotic species are the most common problem faced by lakes. Human activity surrounding lakes has been identified as a factors towards lake degradation. Globally, numerous programs was set up to conserve lakes with the special objective protecting lakes and promoting local sustainable development [3]. Lakes conservation recently becomes the important issues in biodiversity conservation.

Tourism in lake ecosystem is widely observed. Lake is an important tourism attraction in numerous countries. Lakes also used as a media promotion to promotes the tourism destination of particular countries [1]. In Indonesia many lakes is famous for tourism destination and attractions, namely Lake Toba in North Sumatera, Lake Batur and Lake Buyan in Bali, Lake Kelimutu in East Nusa Tenggara, and Lake Tondano in North Sulawesi. The area of fresh water lake, acid lake, and volcanic lake become tourism attraction $[4,5]$. The contribution of lakes as an important part of ecosystem to generated tourist come to particular destination was important. Some place was easy in accessibility, but there are numerous lakes with poor infrastructure

North Sulawesi, Indonesia, is an important area for future tourism development in Indonesia. North Sulawesi has abundance natural resources for sustainable tourism development, including lakes ecosystem [6]. Lakes are important for local development, especially in agricultural and tourism development. There are however, little discussion related to the lakes and 
tourism development in North Sulawesi. The aims of the research are to describes the recent status of lakes in South Sulawesi and describes its opportunities for tourism development. The analysis was based on the secondary data and direct field observation.

\section{LAKE IN SOUTH SULAWESI}

South Sulawesi can be said as landscape with diverse ecosystem, from coastal and small islands to mountain ecosystems. Geographically North Sulawesi province is located at $0^{\circ} 30^{\prime \prime}-4^{\circ} 3^{\prime \prime} N$ and $121^{\circ} 127^{\prime \prime} \mathrm{E}$. The area has equatorial climate with two season, namely rainy season and dry season. North Sulawesi is one of the home of most active volcanoes, leading the soil in North Sulawesi with high fertile characteristic. The natural ecosystem was numerous [6,7].

Besides rivers, lakes is an important fresh water ecosystem in North Sulawesi. The lakes of North Sulawesi was presented in Table 1. Lakes ecosystem in North Sulawesi has relationship with the geological history of the northern tip area of Sulawesi Island. Geologically, this area is considered as one the very active volcanic area, resulting some lakes was exist with volcanic process impact. Many lakes, however, was the fresh water lake ecosystem which area important to support human activity surrounding lakes, especially in agricultural sectors.

Table 1. Lakes of North Sulawesi

\begin{tabular}{clcc}
\hline No. & \multicolumn{1}{c}{ Lakes } & Size (ha) & Regency \\
\hline 1 & Tondano & 4.278 & Minahasa \\
2 & Linow & 35 & Minahasa \\
3 & Wungangaan & 30 & Minahasa \\
4 & Bulilin & 22 & Minahsa \\
5 & Kawelan & 8 & Minahasa \\
6 & Mokobang & 38 & Minahasa \\
7 & Pangolombian & 2 & Minahasa \\
8 & Sendow & 2 & Minahasa \\
9 & Makalehi & 56 & Sangihe-Talaud \\
10 & Tampusu & 3 & Minahasa \\
\hline Source: & National Land Agency, North Sulawesi
\end{tabular}

In relationship with tourism industry, some lakes has been promoted and visited as tourism destination. The contribution of tourism basedlakes for local economic community development was significant. In Lake Tondano, there are growing restaurant in some area in the adjacent of lake ecosystem.

\section{Lake Linow}

Lake Linow located at Tomohon city and widely known as lake with spectacular water color (Fig. 1). Lake Linow was visited by numerous tourist, both domestic and international tourism (Table 2). International tourist visit Lake Linow as part of the as of the tourism package to visit main tourism destination North Sulawesi such as Bunaken. The accessibility of Lake Linow was relatively easy, stimulates tourist from Manado and Tomohon come to Lake Linow. Daily number of tourism was few, lead visitor feel close to nature. Lake Linow represent the natural phenomena of active geological process which cause beautiful color of lake water. This geological aspects was identified few in the world and therefore such phenomena open oppor-tunities to Lake Linow become interested tourism object in the world $[8,9,10]$.

Table 2. Tourism visitation in Lake Linow, Tomohon

\begin{tabular}{llll}
\hline Tourist & $\mathbf{2 0 1 1}$ & $\mathbf{2 0 1 2}$ & $\mathbf{2 0 1 3}$ \\
\hline Domestic tourist & 2.780 & 2.380 & 2.575 \\
International tourist & 1.814 & 1.998 & 1.607 \\
\hline
\end{tabular}

Problems facing Lake Linow is poor planning and development, especially in term of integrative planning and environmental protection in Lake Linow. The important issues related to the Lake conservation is the existence of geothermal plant which is potentially contribute to the degradation of lake ecosystem [9]. Lake Linow also facing potential serious problems of lake degradation caused by rapid agriculture development in an area adjacent to lake ecosystem.

\section{Lake Tondano}

Lake Tondano is the biggest lake in North Sulawesi. This lake is very famous and has promoted as one of the tourism destination in North Sulawesi (Fig.1). Many brochure and tourism magazine introduce Lake Tondano as one of the recommended attraction in South Sulawesi to be visited by tourist in exploring nature of South Sulawesi [10]. In the perspective of national policy planning for tourism development, Tondano area is one of the strategic area for national tourism development. Based on the Law Number 50 of 2011 about National Planning for tourism development 20102025, Tomohon and Tondano has been declared as one of the 88 strategic area for national tourism strategic area (KSPN, Kawasan Strategis Pariwisata Nasional).

Administratively, Lake Tondano belong to the Regency of Minahasa. The lake occupy and area about $46 \mathrm{~km}^{2}$ in dry season and water body able to occupy an area about $51 \mathrm{~km}^{2}$ in rainy season. Normally the lake periphery was about $35.5 \mathrm{~km}$ 
in length. There area about 35 rivers flows (inlet) to lake Tondano and one river outlet called Tondano River. The inlet rivers, lake and outlet (Tondano rivers) is important for community. The water resources has been used to provide water drink of community in Tondano and Manado, electricity plant of Tanggari dan Tonsea Lama, agricultural irrigation, fisheries and tourism [11]. About 14 aquatic plant species found $n$ Lake Tondano, some of them are water invasive species, including Eichornia crassipes. The abundance of exotic species is the impact of nutrient rich in water body [12].

Problem faced by Lake Tondano recently very complicated, bring economic and social aspect into environmental problems. The classical problems of lakes such as sedimentation have been reported by authors as one of the consequences of unmanaged development following sustainable principles. Lake Tondano is one of the sites for aquaculture activity. There are many argument for lake conservation and protection.
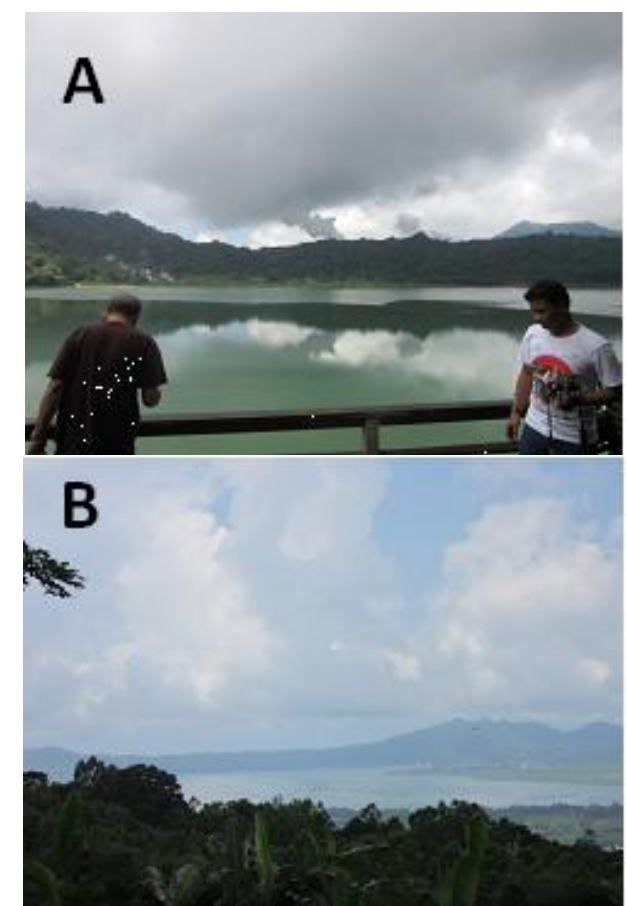

Figure 1. Lake Linow (A) and lake Tondano viewed from Tampusu Highland (B).

\section{Lake Pangolombian}

Lake Pangolombian located at Pangolombian Village at Tomohon. Recently Lake Pangolombian grows as one of the alternative destination for nature-based tourism in Tomohon area. It is located at $911 \mathrm{~m}$ asl in the Minahasa highland ecosystem in geographic position $1^{\circ} 15^{\prime} 50.04^{\prime \prime} \mathrm{N}$ and $124^{\circ} 50^{\prime} 27.24^{\prime \prime}$ E. As far, the data base for flora fauna in Lake Panolombian was absent, indicated there are no research report has been published.

\section{Lake Tampusu}

Lake Tampusu located at the border of Pangolombian village and Tampusu Village. The water body located at the top of Tampusu highland surrounded by 80 ha of mountain forest. In the past, the highland has used as observation point for foreign ship arrivals which will landed in North Sulawesi from southern coastal. Some excursionist has been visited Lake Tampusu lead to the development of infrastructure from Pangolombian to Tampusu. Recently, about $300 \mathrm{~m}$ road to Lake Tampusu has been asphalted, while 100 remains road with stone and gravel. The tourism facility in Lake Tampusu was simple. There are no indication of environmental degradation, including aquatic exotic plant invasion, and sedimentation. Recent nature lovers arrivals in Lake Tampuso, however, should be considered as one of the important stage for tourism development in Lake Tampuso and its surrounding area. The proper planning and management therefore should be planned comprehensively.

\section{LAKE AND TOURISM}

Many lakes in the world have been visited by tourist, representing the important lake of lakes ecosystem as tourism resources. Lake in remotes area with poor infrastructure are often visited by limited number of tourist. Lakes without adequate infrastructure often less developed as tourist attraction and the common uses of lakes often related to the daily activity of local people. To become the tourist destination, lakes need support of tourism infrastructure to facilitate tourist flow to attraction complex. Corridors and transport availability is requested by the development of lake to become attractions

In North Sulawesi, lakes become interested object of tourism activity because lake offer some tourism product aspect which are absent in other attraction types [10]. Landscape sightseeing and enjoying natural setting of lakes is one the favorite activities among tourist in lake. Boating is an alternative tourism activity in lakes. Generally, place with best panorama received a lot of attention from businessman and tourism developers [13]. As observed in some place in Lake Tondano periphery area, the place with good panorama and environmental setting is the spot for restaurant and cottage development. 
Table 3. The Comparison of Lakes Characteristics in North Sulawesi

\begin{tabular}{|c|c|c|c|c|}
\hline Characters & Lake Tondano & Lake Linow & Lake Tampusu & Lake Pangolombian \\
\hline Size (ha) & 4.278 & 35 & 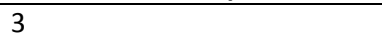 & 2 \\
\hline $\begin{array}{l}\text { Tourism-related } \\
\text { uses }\end{array}$ & Medium-massive & Medium & Few & Few \\
\hline $\begin{array}{l}\text { Number of } \\
\text { visitors }\end{array}$ & Medium & Medium & Few & Few \\
\hline $\begin{array}{l}\text { Accessibility from } \\
\text { Manado }\end{array}$ & $\begin{array}{l}\text { Accessible by public } \\
\text { transportation }\end{array}$ & $\begin{array}{l}\text { Accessible, } \\
\text { supported by city } \\
\text { roads }\end{array}$ & $\begin{array}{l}\text { Accessible until Pangolombian } \\
\text { village, continued by trekking }\end{array}$ & $\begin{array}{l}\text { Accessible, supported } \\
\text { by village roads }\end{array}$ \\
\hline $\begin{array}{l}\text { Volcanic aspect } \\
\text { Tourism } \\
\text { Infrastructure }\end{array}$ & $\begin{array}{l}\text { No } \\
\text { available }\end{array}$ & $\begin{array}{l}\text { Yes } \\
\text { available }\end{array}$ & $\begin{array}{l}\text { No } \\
\text { few }\end{array}$ & $\begin{array}{l}\text { No } \\
\text { few }\end{array}$ \\
\hline
\end{tabular}

The growing popularity of tourism in lake environment has made the industry become priority among place with lake resources. The mutualism between lakes and tourism in many area in was reported by numerous authors. In Indonesia, Lake Toba provides clear evidence of the mutualism relationship between lake and local economic development. The similar case was found in Bali, with four lakes namely Lake Batur (Kintamani), Lake Beratan (Bedugul), Lake Buyan and Lake Tamblingan becomes famous tourism object [5].

In Indonesia, there are several types of lakes which are used as tourism attractions. First is fresh water lakes, such as Lake Toba (North Sumatera), Lake Poso (Central Sulawesi), Lake Tondano (North Sulawesi), and Lake Sarangan (East Java). Second is the mountain crater lake such as Lake Batur (Bali), Ijen crater (East Java), Lake Segoro Anak (West Nusa Tenggara), Lake and Kelimutu (East Nusa Tenggara). These lakes has been contributes to the tourism industry in each province [5].

In North Sulawesi, the comparative of three lakes namely Lake Tondano, Lake Linow and Lake Tampusu has been used in tourism in different levels and impact (Table 3). The different level of tourism used is related to the road infrastructure which are important to facilitate visitor movement and visit natural object. As mention by scholars, road is important factor for visitor movement, especially in tourism destination complex [14].

\section{Lake Conservation and Sustainable Tourism Development}

The issues of sustainable tourism in lake ecosystem emerging as a crucial issues among scholars. Central to the concept of sustainable lake-based tourism destination is the equity of social, ecological and economical aspect in balance. Sustainable tourism practices in lake of North Sulawesi therefore has economic, social and environmental dimensions. There are at least three basic objectives of sustainable tourism in lakes, including North Sulawesi lake's ecosystems. Firstly, development of lake-based tourism should be able to become economic machine to increase business and generating fund to the local government and local community surrounding lakes. Secondly, tourism development should be able to contribute to environmental conservation. Tourism is an important instrument and tools to increase conservation program implementation with the objective protection environment from degradation. In such a case, a comprehensive planning and implementation following environmental standard was important. Thirdly, tourism should be able to increase local people welfare and community development $[14,15]$.

Lake-based tourism development in North Sulawesi has its potentiality to be developed following sustainable destination principles. Through the secondary data analysis and field observation, some aspects related to the development of economy, environment and social aspect need to be highlighted (Table 4).

Table 4. Some Important Aspect Related To The Supporting System in Sustainable Tourism in Lake Environment

\begin{tabular}{|c|c|}
\hline Aspects & Planning Direction \\
\hline Infrastructure & $\begin{array}{l}\text { Promote infrastructure development to facilitate numerous local people movement, including tourism. } \\
\text { Infrastructure for tourist should be developed following safety standard; high quality to facilitate } \\
\text { movement satisfaction }\end{array}$ \\
\hline Accommodation & $\begin{array}{l}\text { Setup following eco-accommodation standard. It should following basic principles such as build using local } \\
\text { material, adopt local architecture, promoting reduce-reuse-recycle principles }\end{array}$ \\
\hline Restaurant & Build following local architectural design, local receipt and material for cuisine, employing local people \\
\hline Visitor centre & In many case ignored. Should be build to facilitate interpretation aspect of ecotourism \\
\hline
\end{tabular}


Economical aspect issues related to the lake development as tourism object related to the issues of:

$>$ Community involvement; Planning involving community from the beginning of planning stage, implementation to share benefits should be fostered. As far, there are indications of poor local people involvements.

$>$ Community economic development; Fostering numerous program to increase local people capacity to be active involved in economic activity in lake-based tourism development.

Ecological aspect issues related to the lake development as tourism object:

$>$ Proper land use planning; Lakes is fragile ecosystem and easily degraded due to the rapid development of adjacent terrestrial ecosystems. Proper land uses planning was needed to ensure lake protection other ecosystem or sites development.

$>$ Environmental protection regulation to enhance the integrity of ecosystem functions. Some aspect related to the potential threats to lakes ecosystem such as aquatic plant invasion, sedimentation and pollution should be minimized.

$>$ Environmental management; to ensure the sustainable use of agricultural and industrial activity in surrounding lakes. It is important to minimize pollution impact of agriculture and industrial activity to lakes ecosystem.

Social aspect which area related to the development of lakes as tourism attraction are encompasses:

$>$ Promoting capacity development. Tourism planning should accommodate local people interest in lake and development issues, including spiritual and social perceptions.

Tourism development socially should be promote social life, developing code and conduct and promoting local culture as an integral part of tourism attractions.

\section{CONCLUSION}

Lake is an important resource for tourism development in North Sulawesi. Four lake in North Sulawesi namely Lake Tondano, Lake Linow, Lake Pangolombian and Lake Tampusu located at the potential cluster for further lakebased tourism destination. The development of lakes as tourism attractions should be allowed following sustainable principles with economical social and environmental aspect become the key for development. The conservation of Lake in North Sulawesi is a crucial issue. It is especially important to create sustainable tourism area for sustainable human life and creative industry in the hearth of South Sulawesi.

\section{Acknowledgement}

The authors wish to thank Dr. Luchman Hakim for providing material and comments to improve the manuscript, and Dr. Regina R. Butar-butar for valuable comment and field trips.

\section{REFERENCES}

[1] Hall, C. M. and T. Härkönen (Eds). 2006. Lake tourism: An integrated approach to lacustrine tourism systems Vol. 32. Channel View Publications.

[2] Scheffer, M. 2004. Ecology of shallow lakes. Springer Science and Business Media.

[3] Bruton, M. N. 1990. The conservation of the fishes of Lake Victoria, Africa: an ecological perspective. Environmental Biology of Fishes 27(3), 161-175.

[4] Hakim, L. 2004. Dasar-dasar ekowisata. Bayumedia.

[5] Ver Berkmoeis, R. 2013. Lonely planet Indonesia (Travel Guide). Paperback. Lonely Planet.

[6] Hakim, L., M. Soemarno and S. K. Hong. 2012. Challenges for conserving biodiversity and developing sustainable island tourism in North Sulawesi Province, Indonesia. Journal of Ecology and Environment 35(2), 61-71.

[7] Whitten, T., G. Henderson and M. Mustafa. 2013. Ecology of Sulawesi. Tuttle Publishing.

[8] Pioh, D. D., M. L. Rayes, B. Polii and L. Hakim. 2013. The classification and characteristics of soil surrounding lake ecosystem as a basic consideration in agrotourism development in Linow Lake, North Sulawesi. IOSR Journal of Agriculture and Veterinary Science 7(5), 30-38.

[9] Boka, R. Y., W. R. Maryunani and L. Hakim. 2013. Local community perception toward the incentive system in the sustainable tourism quality development at Linow Lake, North Sulawesi. IOSR Journal of Business and Management 13(1), 1-6.

[10] Tourism Office of Tomohon City. 2013. Jumlah kunjungan wisatawan (Tourists Visit in Tomohon City). Tomohon Tourism Office.

[11] Sittadewi, E. H. 2011. Fungsi strategis Danau Tondano, Perubahan ekosistem dan 
masalah yang terjadi. Jurnal Teknologi Lingkungan 9(1).

[12] Nebath, J. 2012. Kelimpahan tumbuhan akuatik di Danau Tondano. EKOTON 8(2).

[13] Sampouw, O. G., A. E. Tungka and V. A. Kumurur. 2015. Hotel resort di tepi Danau Tondano, Minahasa "cultural identity". Jurnal Arsitektur DASENG 4(2), 61-70.

[14] Inskeep, E. 1991. Tourism planning: an integrated and sustainable development approach. Van Nostrand Reinhold.

[15] Fennell, D. A. 1999. Ecotourism: an introduction. Routledge. London and New York. 